\title{
Ingen fremgang uten meningsbrytning
}

\begin{abstract}
Det nye året fikk en brutal start da den danske tegneren Kurt Westergaard ble angrepet med øks i sitt eget hjem første nyttårsdag og etter alt å dømme var nær ved å bli drept. Westergaard laget den mest kontroversielle av de 12 tegningene av profeten Muhammed som Jyllands-Posten publiserte i september 2005. Tegningene bidro til å utløse demonstrasjoner og voldshandlinger mange steder i verden. Mer enn hundre mennesker mistet livet, danske og norske flagg ble brent, ambassader stormet. Både Westergaard og Jyllands-Posten er senere blitt truet gjentatte ganger, og han har politibeskyttelse 24 timer i døgnet. Likevel gikk det nesten galt 1. januar 2010.
\end{abstract}

Vi har fått en verden der de geografiske avstandene virker mindre, der teknologien gjør det mulig å spre informasjon og kommunisere med hele verden i løpet av sekunder. Men det er også blitt tydelig at vi er forskjellige - og ikke bare utenpå. Meninger, normer og verdisyn er svært ulike. Hvordan skal vi håndtere det?

«Karikaturstriden» dreier seg ikke først og fremst om reaksjonene på en bestemt tegning, men hvordan vi verdsetter meningsbrytning og ytringsfrihet når meningene og ytringene sårer eller endog krenker andre. Generalsekretær Per Edgar Kokkvold i Norsk Presseforbund er en av dem som tydeligst har forsvart publiseringen av tegningene og som frykter konsekvensene av at norsk og utenlandsk presse, ifølge ham, nærmest er blitt truet til taushet $\mathrm{i}$ denne saken. «Jeg tror det har endret det offentlige rom ganske vesentlig. Når norske og andre medier fortsatt ikke våger å trykke disse harmløse tegningene, er det ikke fordi vi har bøyd oss i respekt for muslimenes tro, men fordi vi har bøyd oss i frykt for islamistenes terror, hvilket vi aldri må finne på å gjøre,» sa Kokkvold på Lørdagsrevyen 2. januar i en kommentar til angrepet på Westergaard. Han fortsatte: «Retten til å tenke og uttrykke sine tanker, retten til å tro uten å mene at man har rett til å ta livet av de som tror noe annet, er så fundamentalt for hele vår livsform at vi faktisk i noen situasjoner er nødt til å markere at her går grensen.»

Westergaard selv er også helt klar på at han ikke angrer eller ønsker å unnskylde tegningen. «Jeg har bare arbeidet i mitt fags traditioner, og jeg vil ikke acceptere, at nogen form for ondskap skal dominere mitt liv,» sa han til Politiken 4. januar 2010 (1). Han forteller også at han har diskutert ulike fortolkninger av tegningen med muslimer uten å komme noen vei. «Jeg havde ikke forestillet mig, at vi ble enige. Men jeg hadde forestillet mig, at vi ville acceptere, at uenigheter i et demokrati, dem snakker man om, man skændes, man råber, men ingen diskussioner skal jo ende med en begravelse.»

Nei, diskusjoner skal selvsagt ikke ende med begravelse. Fri meningsutveksling og respekt for uenighet er ikke viktig bare for enkeltmennesket, det betyr mye for samfunnet som helhet. Det er vanskelig, hvis ikke umulig, å se for seg fremskritt og utvikling uten debatt og kontroverser. Og det er like vanskelig å se for seg reell meningsbrytning uten at noen føler seg såret eller tråkket på tærne.

Spørsmålet om ytringsfrihet og ytringsform er vesentlig for all offentlig debatt og for alle publikasjoner - også Tidsskriftet (2). Hvem som skal komme til orde, med hva, når og på hvilken måte, det er sentrale spørsmål i enhver redaksjon. Hvordan spørsmålene besvares, gjenspeiler publikasjonens redaksjonelle linje. I et vitenskapelig tidsskrift er dette viktig, for forskning er ikke bare undersøkelser, men også kontroverser - om funn, forklaringer og metoder. Derfor er det ikke nok å ha tilfredsstillende kriterier for hva som skal komme på trykk og et bevisst forhold til hva som holder mål faglig. Det er like nødvendig å ha systemer for kommentarer og korreksjoner og retningslinjer for hvordan uenighet skal komme til uttrykk (3).

A tåle kritikk og akseptere at andre har helt andre synspunkter enn en selv, er krevende, men det er en helt nødvendig forutsetning for fremskritt og utvikling. I vårt fag er åpen meningsutveksling særlig viktig, fordi medisinsk praksis ikke bare er basert på rutiner og prosedyrer, men vel så mye på kultur, etikk, verdier og preferanser. Tidsskriftet har alltid inneholdt mye debatt, ikke minst i spalten Brev til redaktøren. Ved dette årsskiftet ønsker vi å løfte meningsutvekslingene enda tydeligere frem ved å samle ledere og debattinnlegg foran i bladet. Vi gjør ikke dette for å friske opp layouten og gjøre bladet lettere å lese. Vi gjør det for å understreke hvor viktig tydelige meninger, kritikk og diskusjon er for faget og for god legevirksomhet.

Leger diskuterer gjerne rent faglige spørsmål og skriver gjerne. Det kan være vanskeligere å få kolleger til å ytre seg om organisering og prioritering av helsetjenester til tross for at slike spørsmål kan ha like stor medisinsk betydning. Vi ønsker oss flere og dristigere innlegg om helsepolitiske emner. Det fortjener pasientene!

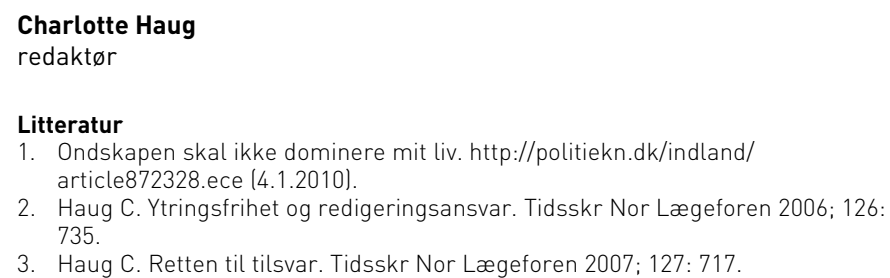

